\title{
Information Dashboard Penjualan Produk Fashion Muslim di DKI Jakarta Sebagai Pendukung Strategi Pemulihan Ekonomi Nasional
}

\author{
(DKI Jakarta Fashion Muslim Sales Information Dashboard for Supporting National Economic \\ Recovery Policy)
}

\author{
Muhammad Fachry Nazuli ${ }^{*}$, Nasiya Alifah Utami², Salwa Rizqina Putri ${ }^{3}$ \\ 1,2,3 Politeknik Statistika STIS (Komputasi Statistik) \\ Email:221810452@stis.ac.id
}

\begin{abstract}
ABSTRAK
Untuk memaksimalkan potensi penjualan produk fashion muslim di DKI Jakarta melalui e-commerce sebagai salah satu strategi peningkatan aktivitas dunia usaha yang dicanangkan oleh pemerintah dalam Pemulihan Ekonomi Nasional (PEN), stakeholder, dalam hal ini pemerintah dan pelaku usaha, perlu mengetahui pola penjualan produk fashion muslim. Penelitian ini bertujuan untuk menganalisis secara deskriptif penjualan produk fashion muslim di DKI Jakarta melalui $e$ commerce dan membangun information dashboard menggunakan javascript untuk visualisasi data serta json untuk menyimpan data. Data yang digunakan adalah data penjualan produk fashion muslim di wilayah DKI Jakarta pada 19 April-11 Mei 2021 yang diambil dengan metode web-scraping pada website Tokopedia. Information dashboard pada penelitian ini berhasil dibangun dengan performa baik. Secara umum, penjualan produk fashion muslim cenderung tinggi di awal dan di pertengahan bulan Ramadhan. Wilayah DKI Jakarta dengan kontribusi penjualan produk fashion muslim terbanyak adalah Jakarta Pusat, sedangkan wilayah dengan omset penjualan produk fashion muslim tertinggi adalah Jakarta Barat.
\end{abstract}

Kata kunci: PEN, e-commerce, Ramadhan, DKI Jakarta, information dashboard

\begin{abstract}
In order to optimize the sales potential of Muslim fashion products in DKI Jakarta through e-commerce, as one of the strategies for increasing business activity defined by the government in the National Economic Recovery (PEN) policy, stakeholders, that is the government and business actors, need to know the sales pattern of Muslim fashion products. This study aims to analyze descriptively the sales of Muslim fashion products in DKI Jakarta through e-commerce and develop an information dashboard using javascript for data visualization and JSON for storing data. The data used is sales data of Muslim fashion products in the DKI Jakarta on April 19-11 May 2021 which collected using web-scraping method on the Tokopedia website. The information dashboard in this study was successfully developed with good performance. In general, sales of Muslim fashion products disposed to be high in the early and mid-Ramadhan months. DKI Jakarta area with the highest sales contribution of Muslim fashion products is Central Jakarta, while the area with the highest sales turnover of Muslim fashion products is West Jakarta.
\end{abstract}

Keywords: PEN, e-commerce, Ramadhan, DKI Jakarta, information dashboard

\section{PENDAHULUAN}

Sejak kemunculannya pertama kali pada Desember 2019 di Wuhan, China, COVID-19 telah memberikan dampak besar terhadap perekonomian dunia. Lembaga finansial internasional JP Morgan menyebutkan pertumbuhan ekonomi global akan minus 1,1 persen dan International Monetary Fund (IMF) memproyeksikan keadaan ekonomi global turun minus di angka 3\% (Pakpahan, 2020). Hal yang serupa juga dialami Indonesia, menurut laporan Badan Pusat Statistik (BPS) Republik Indonesia, pertumbuhan ekonomi Indonesia mengalami kontraksi sepanjang 2020 sebesar 2,07\% dibandingkan 2019 (Ariyanti A, 2021).

Guna mengatasi permasalah ekonomi Indonesia akibat pandemi, pemerintah mencanangkan kebijakan pemulihan ekonomi nasional atau PEN sebagai strategi jangka pendek. Kebijakan yang diterapkan meliputi peningkatan konsumsi dalam negeri, peningkatan aktivitas dunia usaha, serta penjagaan stabilitas ekonomi dan ekspansi moneter (Nainggolan, 2020). Upaya pemerintah dalam menggerakkan dunia usaha dilakukan melalui pemberian bantuan kepada UMKM dan koperasi. Selain itu, kebijakan struktural yang berfokus pada pengenalan dan penggunaan teknologi digital bagi UMKM sekaligus persiapan untuk memasuki era Industri 4.0 diperlukan sebagai solusi permasalahan jangka panjang (Pakpahan, 2020).

Pada rumusan kebijakan PEN yang kedua yakni peningkatan aktivitas dunia usaha, e-commerce dapat menjadi salah satu opsi yang diambil. Hal ini sejalan dengan fakta bahwa $e$-commerce merupakan salah satu pendorong utama yang menjadikan Indonesia sebagai negara dengan nilai ekonomi digital terbesar di 
Asia Tenggara mencapai \$40 miliar pada tahun 2019 dan diprediksi meningkat hingga \$130 miliar pada tahun 2025 (Dinisari, 2020). Aktivitas e-commerce sangat potensial di era pandemi karena kegiatan jual beli dapat berlangsung tanpa keterbatasan pandemi. Terlebih lagi, imbauan pemerintah untuk membatasi aktivitas keluar rumah membuat e-commerce menjadi opsi yang diminati dan tepat. Salah satu situs $e$-commerce dalam negeri yang mengalami perkembangan pesat ialah Tokopedia. Survei yang dilakukan oleh iPrice pada tahun 2019 yang bertujuan untuk mengetahui layanan e-commerce yang paling sering digunakan oleh masyarakat, membuktikan bahwa e-commerce yang paling sering dikunjungi adalah Tokopedia dengan jumlah penggunanya 66 juta pengunjung. Sedangkan situs e-commerce pesaingnya yaitu Shopee, 56 juta pengunjung, Bukalapak, 42,9 juta pengunjung, dan Lazada, 28 juta pengunjung (Bertuah, et al., 2021).

Aktivitas e-commerce meningkat selama bulan ramadhan, khususnya pada produk fashion muslim. Menurut Ekhel Chandra Wijaya selaku External Communications Senior Lead Tokopedia, penjualan produk kategori fashion muslim pada Tokopedia meningkat hampir empat kali lipat dibanding rata-rata bulanan 2021 (Tokopedia, 2021). Menurut Asosiasi Ritel Indonesia (APRINDO), menjelang Idul Fitri penjualan produk pakaian meningkat drastis yaitu antara 200 hingga 300 persen (Mardiah, 2017). Berdasarkan publikasi BPS mengenai statistik e-commerce Indonesia, daerah dengan persentase usaha e-commerce tertinggi tahun 2020 adalah DKI Jakarta yakni sebesar $96,58 \%$. Hal ini sejalan dengan DKI Jakarta yang merupakan pusat kegiatan ekonomi nasional. Oleh karena itu, analisis penjualan produk fashion muslim Tokopedia di DKI Jakarta dipilih sebagai studi kasus dalam penelitian ini.

Untuk memaksimalkan potensi penjualan produk fashion muslim di DKI Jakarta melalui e-commerce sebagai salah satu strategi peningkatan aktivitas dunia usaha yang dicanangkan oleh pemerintah dalam Pemulihan Ekonomi Nasional (PEN), stakeholder yang berkepentingan, dalam hal ini pemerintah dan pelaku usaha, perlu mengetahui pola penjualan produk fashion muslim. Menurut penelitian Vito Vincentdo (2019), hasil pengolahan data transaksi pada e-commerce yang divisualisasikan melalui dashboard dapat berguna dalam mengelola dan mempersiapkan strategi serta dapat menjadi tombak untuk memaksimalkan penjualan. Selain itu, visualisasi data yang dapat memberikan pemahaman, menggunakan teknologi visualisasi yang tepat, dan memungkinkan pembaruan secara berkala dapat membantu dalam pengambilan keputusan oleh pemerintah (Moore, 2017). Sampai sejauh ini belum ada rujukan mendetail mengenai pola penjualan produk fashion muslim khususnya di bulan Ramadhan yang dapat dijadikan dasar dalam pengambilan keputusan. Oleh karena itu, perlu dibangun information dashboard sebagai media bagi stakeholder untuk melihat potensi $e$ commerce sehingga dapat meningkatkan aktivitas dunia usaha demi pemulihan ekonomi Indonesia.

Berdasarkan latar belakang diatas, dirumuskan dua tujuan yang ingin dicapai pada penelitian ini. Pertama, menganalisis penjualan produk fashion muslim di DKI Jakarta melalui e-commerce, khususnya Tokopedia. Kedua, menyajikan information dashboard data penjualan produk fashion muslim selama bulan Ramadhan pada website yang dapat diakses oleh stakeholder. Diharapkan, information dashboard yang dibangun ini dapat memberikan informasi kepada pemerintah daerah dan masyarakat umum sebagai pelaku usaha mengenai potensi e-commerce khususnya produk fashion muslim di daerahnya sehingga dapat mendukung kebijakan strategi pemulihan ekonomi nasional (PEN).

\section{METODE}

Penelitian ini terdiri dari enam tahapan utama, yakni pengumpulan data, preprocessing data, perancangan visualisasi dashboard, pembangunan dashboard, analisis data, dan uji performa dashboard.Tahapan penelitian yang dilakukan digambarkan dalam sebuah diagram alir (flowchart) pada Gambar 1.

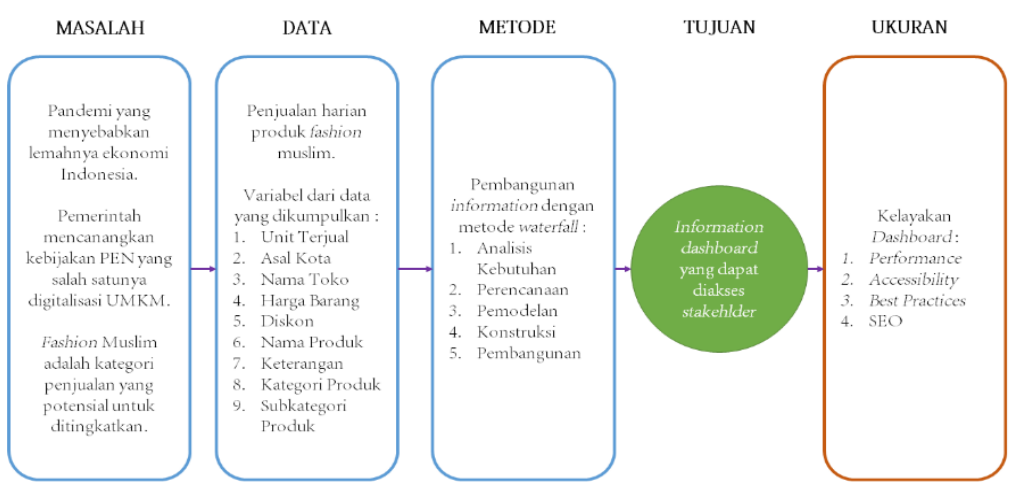

Gambar 1. Diagram Alir Tahapan Penelitian 
Tahapan penelitian yang telah digambarkan pada Gambar 1 diuraikan masing-masing sebagai berikut.

\section{Pengumpulan Data dan Preprocessing}

Data yang digunakan dalam penelitian ini dikumpulkan dengan metode web scraping. (A. Yani et al., 2019) Web scraping adalah teknik untuk mendapatkan informasi dari situs web secara otomatis tanpa harus menyalinnya secara manual. Tujuan dari web scraping adalah untuk mencari informasi pada bagian tertentu. Pada penelitian ini, web scraping dilakukan pada salah satu marketplace di Indonesia yakni Tokopedia dalam kurun waktu bulan Ramadhan tahun 2021 yakni mulai 19 April 2021 hingga 11 Mei 2021. Scraping data dilakukan setiap dua hari. Adapun produk yang diambil datanya adalah produk fashion muslim dengan pembagian kategori dan subkategori seperti yang tercantum pada tabel 1.

Tabel 1. Pembagian Kategori dan Subkategori Produk Fashion

\begin{tabular}{ccccccccc}
\hline No. & Kategori & Subkategori & No. & Kategori & Subkategori & No. & Kategori & Subkategori \\
\hline 1 & Pakaian & Gamis & 12 & Jilbab & Jilbab & 22 & Bawahan & Kulot \\
2 & Anak & Koko & 13 & & Pashmina & 23 & Wanita & Rok \\
3 & & Busana Muslim & 14 & & Khimar & 24 & Dress Wanita & Abaya \\
4 & & Jilbab & 15 & & Turban & 25 & & Gamis \\
5 & & Mukena & 16 & Pakaian Pria & Koko & 26 & & Jumpsuit \\
6 & & Sarung & 17 & & Celana Sarung & 27 & & Kaftan \\
7 & & Peci & 18 & & Celana Sirwal & 28 & Perlengkapan & Mukena \\
8 & Atasan & Blouse & 19 & & Gamis & 29 & Ibadah & Sajadah \\
9 & Wanita & Manset & 20 & & Peci & 30 & & Sarung \\
10 & & Baju Syari & 21 & & Sorban & 31 & & Tasbih \\
11 & & Tunik & & & & & & \\
\hline
\end{tabular}

Sumber: Data Pribadi

Setelah data dikumpulkan dengan metode web scraping, dilakukan tahapan preprocessing. Preprocessing data merupakan proses pembersihan data mentah hasil web scraping menjadi suatu informasi atau data yang lebih berguna untuk analisis dan proses selanjutnya. (Junaedi, 2011) Preprocessing data dilakukan untuk memperbaiki kualitas data yang dapat memepengaruhi kualitas analisis. Adapun hal yang dilakukan pada tahapan ini adalah split column, join data per hari, dan agregasi data produk sesuai dengan kategori beserta wilayahnya.

\section{Perancangan Visualisasi Data}

Tahapan selanjutnya setelah preprocessing adalah perancangan visualisasi data. Perancangan visualisasi data dilakukan agar data dapat disajikan dengan tools yang tepat dan efektif dalam dashboard. (Lee C., 2018) Sebuah visualisasi yang efektif harus dapat menjelaskan data yang disajikan dengan baik dan membangkitkan rasa ingin tahu dari pembacanya, sehingga penggunaan alat visualisasi yang tepat sangat dibutuhkan.Visualisasi data pada penelitian kali ini dilakukan dengan menggambarkan data dalam enam bentuk diagram yang berbeda. Jenis diagram yang digunakan adalah line chart, bar chart, pie chart, choropleth map, dan radar chart.

Dalam visualisasi data, diperlukan preattentive properties untuk menyampaikan data secara efektif dalam bentuk tertentu. (Summers S. H. 2017) Preattentive properties digunakan dalam visualisasi data untuk mengarahkan perhatian pembaca data kepada fokus informasi yang hendak disampaikan. Pada penelitian ini beberapa Preattentive properties digunakan dalam visualisasi pada dashboard. Properti yang pertama adalah warna. Properti warna yang digunakan dalam visualisasi adalah properti Hue dan Lightness. Hue adalah aspek warna yang dapat kita gambarkan dengan nama seperti "merah", "hijau", dan lain sebagainya (Mazza, 2008). Sedangkan Lightness adalah konsep yang mengacu pada intensitas warna tertentu dari gelap ke tone yang lebih terang (Mazza, 2008). Properti hue digunakan untuk memvisualisasikan data per kategori seperti pada line chart, kemudian lightness digunakan untuk memvisualisasikan data pada choropleth map. Properti berikutnya adalah Bentuk atau Form. Properti bentuk yang digunakan dalam visualisasi data adalah properti length dan size. Properti length digunakan dalam visualisasi seperti diagram bar sedangkan size digunakan dalam pie chart. Properti yang terakhir adalah properti spatial yang digunakan untuk memvisualiasikan data yang memiliki atribut wilayah. Pada visualisasi dilakukan penentuan posisi dua dimensi untuk memvisualisasikan 
data. Hal ini dilakukan untuk memvisualisasikan data menggunakan line chart, radar chart, dan choropleth map.

Selain unsur preattentive, untur interaktif juga diperlukan dalam memvisualisasikan data dalam dashboard. (Namitha, K., 2021) Unsur interaktif dalam visualisasi berfungsi untuk meningkatkan efektifitas penyampaian data dan informasi dalam dashboard. Pada penelitian ini, digunakan tiga jenis unsur interaktif, yakni selection, filtering dan navigation. Unsur interaktif selection merupakan unsur interaktif digunakan untuk memunculkan detail data dari elemen grafik/diagram yang di hover (Mazza, 2008). Unsur filtering pada dashboard diaplikasikan dalam bentuk dropdown menu. Dropdown menu ini digunakan untuk memilih filter pada grafik sehingga grafik dapat ditampilkan sesuai keinginan pembaca data. Filter yang mungkin digunakan adalah filter kota, filter kategori produk, filter tanggal. Unsur interaktif navigation diaplikasikan untuk membuat user dapat melihat visualisasi dengan lebih fleksibel (Mazza, 2008). Fitur navigasi yang disediakan di antaranya panning, rotating, dan zooming.

\section{Pembangunan Information Dashboard}

Metode yang digunakan dalam proses pembangunan information dashboard ini adalah metode waterfall. Metode ini dipilih karena pelaksanaannya yang bertahap sehingga dapat menghasilkan dashboard yang lebih maksimal dan juga cocok untuk pembangunan dashboard baru atau mulai dari awal (Wahid A. A., 2020). metode ini terdiri dari yang terdiri dari lima tahapan proses. Proses dalam metode ini digambarkan dalam diagram alir pada Gambar 2.

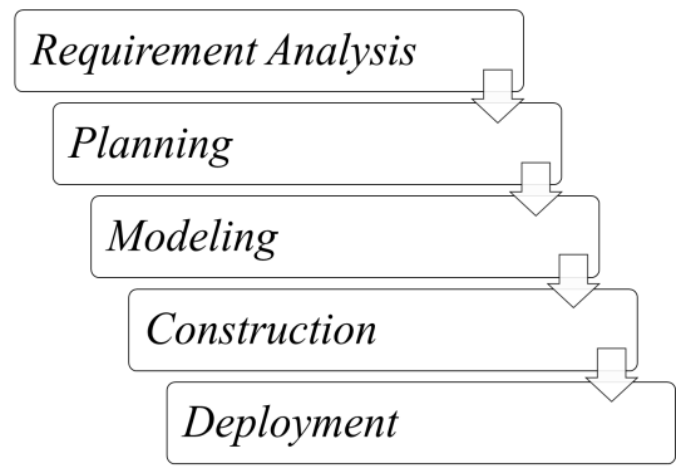

Gambar 2. Metode Waterfall Dalam Proses Pembangunan Dashboard

Pembangunan dashboard dimulai dari requirement analysis yang dilakukan untuk mendefinisikan target pengguna dan kebutuhan pengguna. Planning dilakukan untuk merencanakan penelitian yang akan dikerjakan mulai dari jadwal hingga tekonologi yang akan digunakan. Selanjutnya, modelling dilakukan dengan merancang visualisasi data dan antarmuka pengguna dalam bentuk mockup design. Perancangan antarmuka dashboard dilakukan dengan menggunakan Figma. Hal ini dikarenakan Figma mewadahi pembangunan mockup design secara terintegrasi oleh beberapa orang sekaligus. Berdasarkan rancangan yang dibuat sebelumnya, dilakukan konstruksi struktur dasar dashboard pada tahap construction. Teknologi pendukung dalam pembangunan atau konstruksi information dashboard ini adalah penggunaan bahasa pemrograman CSS, PHP, JavaScript dan format data JSON. Untuk template JavaScript yang digunakan adalah Chart.js yang digunakan untuk visualisasi data dan tableau.js digunakan untuk visualisasi data berbentuk map. Tahap terakhir, deployment, dilakukan dengan membangun dashboard terintegrasi. Untuk melakukan konstruksi dashboard secara terintegrasi, dilakukan pembangunan dashboard dengan gitlab. Hal ini bertujuan untuk mempermudah proses pembangunan dashboard oleh beberapa developer sekaligus dalam waktu yang bersamaan. Setelah proses pembangunan dashboard secara terintegrasi telah rampung, dilakukan publishing dashboard ke web hosting agar dashboard visualisasi data yang dibangun dapat dilihat secara online kapanpun dan dimanapun oleh target pengguna atau stakeholder.

\section{Uji Performa Dashboard}

Untuk melakukan pengujian kebaikan suatu website dapat menggunakan salah satu extension pada Google Crome yaitu Lighthouse. Lighthouse merupakan aplikasi yang dibangun oleh Google yang bersifat open-source. Lighthouse akan menjalankan pengujian terhadap halaman website dan akan memberikan laporan seberapa baik halaman tersebut. Terdapat beberapa aspek yang diuji oleh lighthouse yaitu kinerja (performance), aksesibilitas (accessibility), best practices, SEO, dan lainnya (Google Developers, 2020). 


\section{HASIL DAN PEMBAHASAN}

\section{Fitur-Fitur Dashboard}

Sidebar

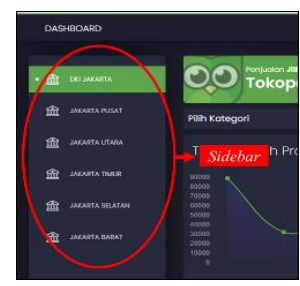

Gambar 3. Tampilan Sidebar pada Dashboard
Fitur sidebar pada information dashboard yang dibangun berisi pilihan daerah visualisasi penjualan produk, yakni Provinsi DKI Jakarta, Kota Jakarta Pusat, Kota Jakarta Utara, Kota Jakarta Timur, Kota Jakarta Selatan, dan Kota Jakarta Barat. Pilihan daerah ini bertujuan untuk menampilkan halaman visualisasi data sesuai dengan daerah yang diinginkan oleh pengguna dashboard atau stakeholder. Tampilan sidebar pada dashboard yang dibangun disajikan dalam Gambar 3.

\section{Dropdown Menu}

Fitur dropdown menu pada information dashboard yang dibangun merupakan fitur untuk melakukan filter pada data visualisasi berdasarkan kategori produk fashion muslim. Hal ini bertujuan untuk menampilkan halaman visualisasi data berdasarkan kategori yang dipilih oleh pengguna dashboard atau stakeholder. Tampilan dropdown menu pada dashboard yang dibangun disajikan dalam Gambar 4.

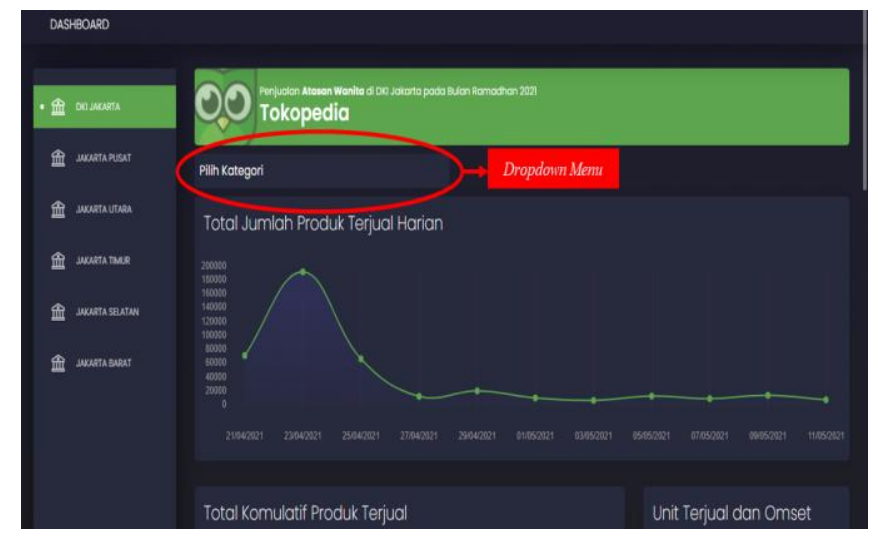

Gambar 4. Tampilan Dropdown Menu pada Dashboard

\section{Fitur Visualisasi Data}

Terdapat lima jenis fitur visualisasi yang digunakan pada dashboard, yakni line chart, choropleth map, bar chart, radar chart, dan pie chart. Line chart digunakan untuk menunjukkan jumlah harian dan kumulatif barang yang terjual per hari. Terdapat tiga buah line chart kumulatif pada visualisasi ini yaitu jumlah kumulatif barang yang terjual per hari, jumlah kumulatif barang yang terjual per hari per kota, dan jumlah kumulatif barang yang terjual per hari per kategori. Choropleth map digunakan untuk menggambarkan jumlah produk terjual dan total omset penjualan dalam kurun waktu 19 April 2021 hingga 11 Mei 2021. Visualisasi data menggunakan choropleth map dilengkapi dengan fitur choose measure (pilih ukuran), yakni untuk memilih data apa yang akan ditampilkan, data jumlah produk terjual atau data total omset penjualan. Bar chart digunakan untuk menunjukkan perbandingan data, dalam hal ini untuk memvisualisasi rata-rata kuantitas penjualan dalam satu hari berdasarkan kota, rata-rata kuantitas penjualan berdasarkan kategori maupun sub kategori. Radar chart digunakan untuk memvisualisasikan data penjualan produk tiap kategori dan kota. Pie chart digunakan untuk memvisualisasikan total jumlah produk tiap kategori dan total jumlah produk dengan pemberian diskon yang dibagi dalam beberapa kategori.

\section{Tampilan Halaman Dashboard}

Tampilan halaman dashboard menggunakan tema black dashboard yang mengambil warna latar hitam. Tampilan awal saat dashboard di-load adalah tampilan halaman visualisasi data secara keseluruhan Provinsi DKI Jakarta tanpa filter kota dan tanpa filter kategori. Tampilan visualisasi data akan berubah ketika filter kota dipilih melalui sidebar dan filter kategori dipilih melalui dropdown menu. Berikut adalah tampilan dashboard yang dibangun. 

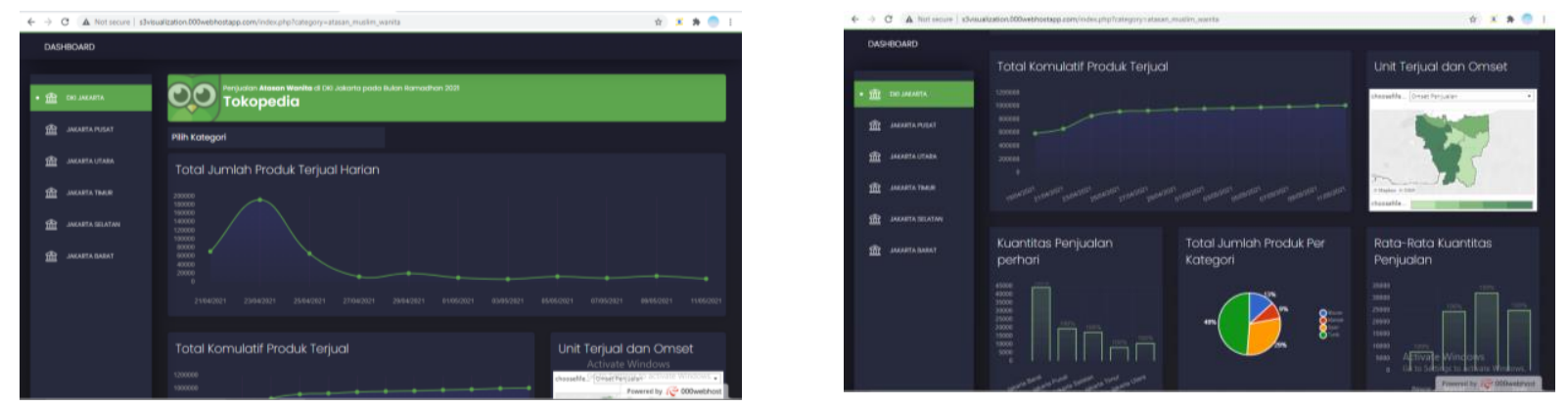

Gambar 5. Tampilan Halaman Dashboard

\section{Pola Penjualan Fashion Muslim di Tokopedia Selama Bulan Ramadhan}

\section{Pola Penjualan Fashion Muslim di DKI Jakarta}

1) Analisis Menurut Waktu

Analisis menurut waktu dilakukan dengan melihat pola pada line chart. Gambar 6 menunjukkan line chart penjualan harian produk fashion muslim di Tokopedia selama bulan Ramadhan.

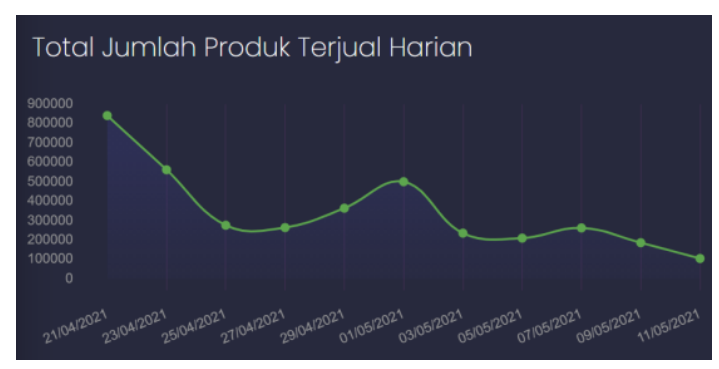

Gambar 6. Plot Harian Penjualan Produk Fashion Muslim di DKI Jakarta

Berdasarkan plot tersebut dapat terlihat bahwa penjualan produk tinggi di hari-hari pertama bulan Ramadhan kemudian menurun. Penjualan kemudian naik di pertengahan bulan Ramadhan dan turun kembali di akhir-akhir bulan Ramadhan. Hal ini menunjukan bahwa penjual produk fashion muslim di DKI Jakarta perlu memperbanyak stok barangnya di awal dan di pertengahan bulan Ramadhan.

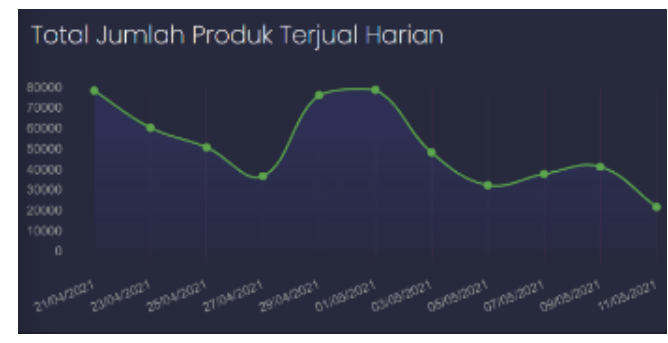

a. Penjualan Pakaian Muslim Pria

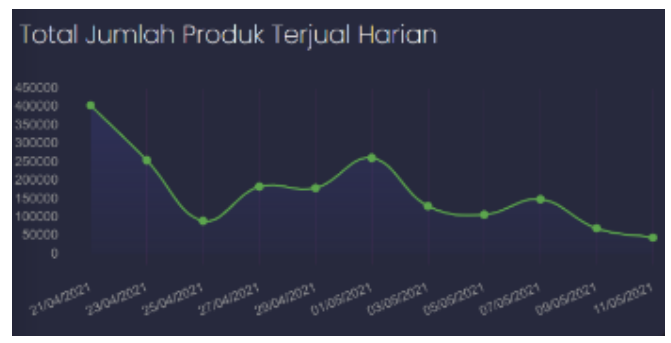

b. Penjualan Peralatan Ibadah

Gambar 7. Plot Harian Penjualan Produk Fashion Muslim di DKI Jakarta Menurut Kategorinya

Gambar 7 menunjukkan plot harian penjualan menurut kategori, pada pembahasan ini kategori yang diambil adalah penjualan pakaian muslim pria dan peralatan ibadah. Berdasarkan plot tersebut dapat terlihat bahwa secara umum, penjualan produk kategori memiliki pola yang sama yaitu tinggi di hari-hari pertama bulan Ramadhan kemudian menurun. Penjualan naik kembali di pertengahan bulan Ramadhan dan turun kembali di akhir bulan Ramadhan. Hal ini menunjukan bahwa penjual produk fashion muslim kategori pakaian muslim pria dan peralatan ibadah di DKI Jakarta perlu memperbanyak stok barangnya di awal dan di pertengahan bulan Ramadhan.

\section{2) Analisis Menurut Kategori}

Analisis menurut kategori dilakukan dengan melihat pola pada bar chart. Gambar 8 menunjukkan bar chart penjualan harian produk fashion muslim di Tokopedia selama bulan Ramadhan. 


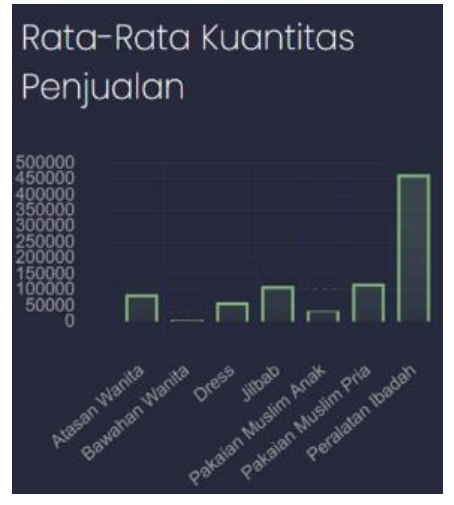

Gambar 8. Bar Chart Penjualan Rata-Rata Harian Produk Fashion Muslim Menurut Kategorinya

Berdasarkan bar chart tersebut, dapat terlihat bahwa penjualan terbanyak terjadi pada produk fashion muslim kategori peralatan ibadah kemudian dilanjutkan pakaian muslim pria, dan jilbab. Penjualan paling sedikit terjadi pada produk kategori bawahan wanita.

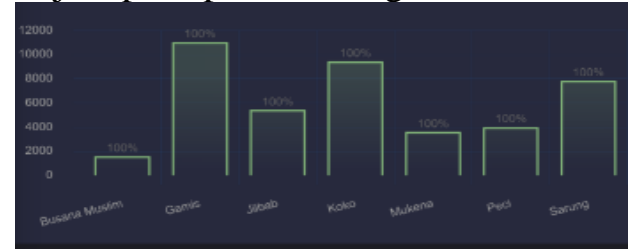

a. Penjualan Pakaian Muslim Anak

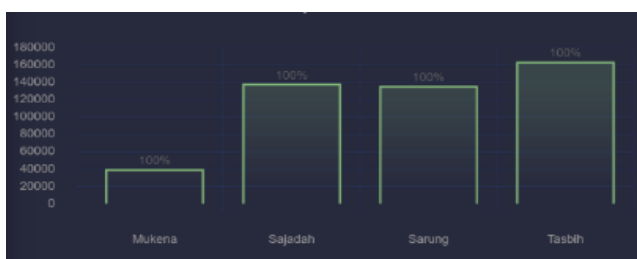

c. Penjualan Peralatan Ibadah

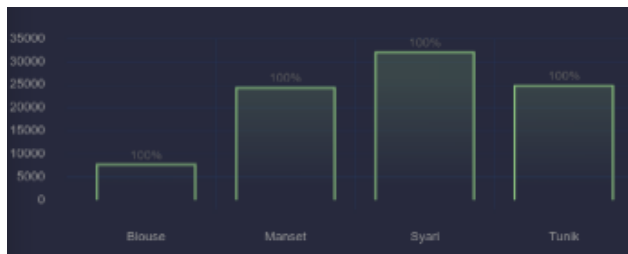

b. Penjualan Atasan Muslim Wanita

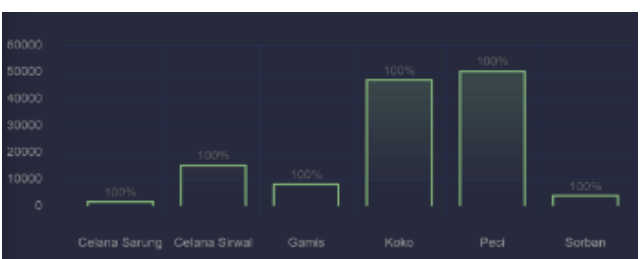

d. Penjualan Pakaian Muslim Pria

Gambar 9. Bar Chart Penjualan Rata-Rata Harian Produk Fashion Muslim di DKI Jakarta Menurut Sub Kategorinya di DKI Jakarta

Gambar 9 menunjukkan beberapa penjualan rata-rata harian produk fashion muslim di DKI Jakarta menurut sub kategorinya. Dapat terlihat bahwa penjualan rata-rata harian produk pakaian muslim anak paling banyak terjadi pada sub kategori gamis, penjualan rata-rata harian produk atasan muslim wanita paling banyak terjadi pada sub kategori syari, penjualan rata-rata harian produk bawahan muslim wanita paling banyak terjadi pada sub kategori rok, penjualan rata-rata harian produk pakaian muslim pria paling banyak terjadi pada sub kategori peci, penjualan rata-rata harian produk peralatan ibadah paling banyak terjadi pada sub kategori tasbih.

\section{Pola Penjualan Produk Fashion Muslim pada Masing-Masing Kota di DKI Jakarta}

\section{a. Analisis Unit Terjual dan Omset Penjualan}

Analisis menurut unit terjual dan omset penjualan dilakukan dengan menggunakan choropleth map dan bar chart. Gambar 10 menunjukkan choropleth map dan bar chart penjualan harian produk fashion muslim di Tokopedia selama bulan Ramadhan.

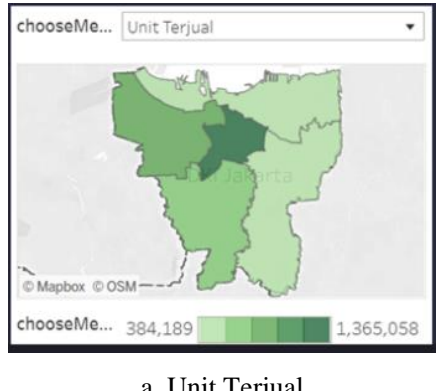

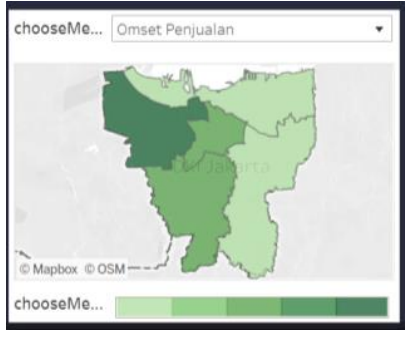

b. Omset Penjualan

Gambar 10. Choropleth Map Unit Terjual dan Omset Penjualan Produk Fashion Muslim di DKI Jakarta 
Berdasarkan gambar tersebut, dapat terlihat bahwa Jakarta Pusat adalah kota dengan unit penjualan tertinggi sedangkan Jakarta Barat adalah kota dengan omset penjualan tertinggi. Hal ini mengindikasikan bahwa barang yang terjual di Kota Jakarta Barat adalah barang dengan nilai jual yang tinggi.

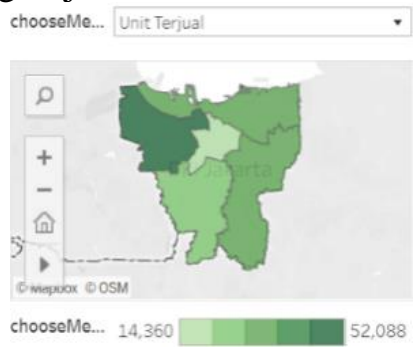

a. Penjualan Pakaian Muslim Anak

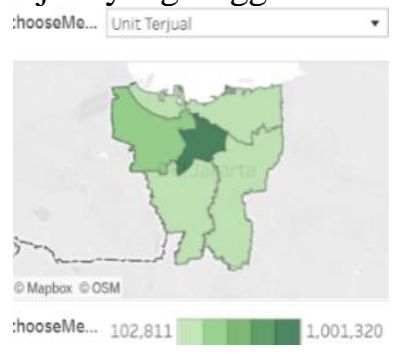

b. Penjualan Peralatan Ibadah

Gambar 11. Choropleth Map Penjualan Produk Fashion Muslim di DKI Jakarta Menurut Kategorinya di DKI Jakarta

Gambar 11 menunjukkan choropleth map penjualan produk fashion muslim di DKI Jakarta menurut kota pada kategori pakaian muslim anak dan peralatan ibadah. Berdasarkan gambar tersebut, dapat terlihat bahwa setiap kategori memiliki jumlah penjualan yang berbeda di tiap kota yang berbeda tetapi, secara umum, penjualan tertinggi berada di Kota Jakarta Barat dan Jakarta Pusat.

\section{b. Analisis Unit Terjual Tiap Kategori}

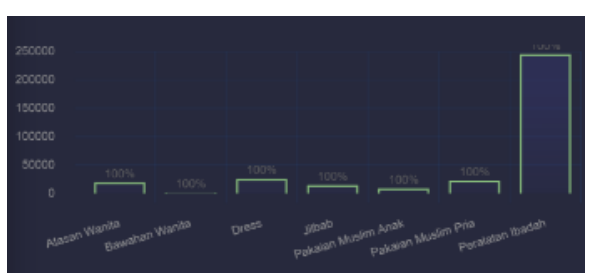

a. Penjualan di Jakarta Pusat

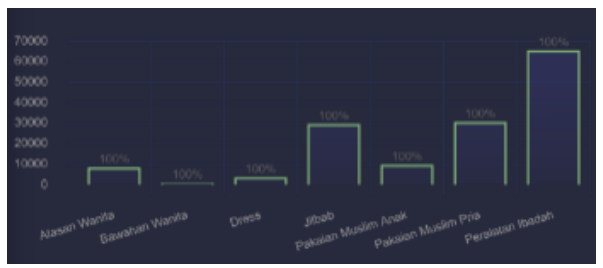

c. Penjualan di Jakarta Timur

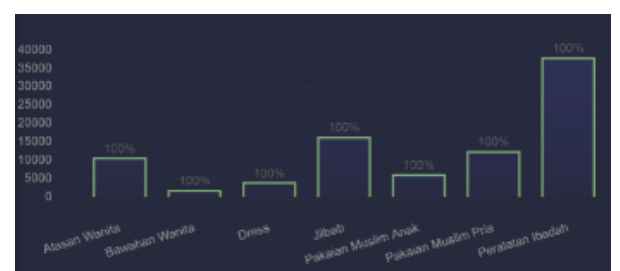

b. Penjualan di Jakarta Utara

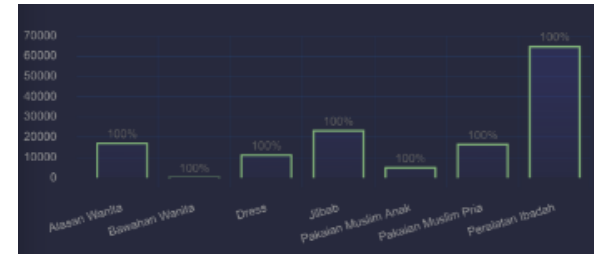

d. Penjualan di Jakarta Selatan

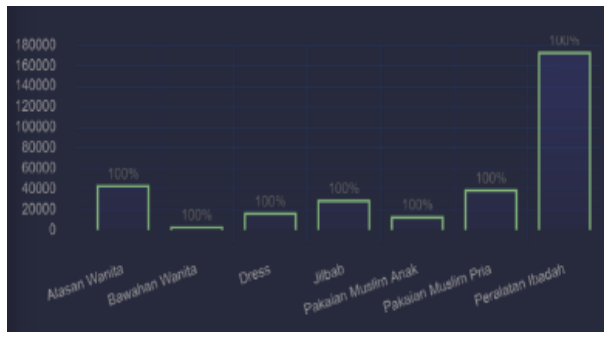

e. Penjualan di Jakarta Barat

Gambar 12. Bar Chart Penjualan Rata-Rata Harian Produk Fashion Muslim Menurut Kategorinya pada Tiap Kota di DKI Jakarta

Gambar 12 menunjukkan penjualan rata-rata harian produk fashion muslim menurut kategorinya pada tiap kota di DKI Jakarta. Berdasarkan plot tersebut, dapat terlihat bahwa penjualan rata-rata harian di Jakarta Pusat tertinggi terjadi pada kategori peralatan ibadah, penjualan rata-rata harian di Jakarta Utara tertinggi terjadi pada kategori peralatan ibadah kemudian kategori jilbab dan pakaian muslim pria, penjualan rata-rata harian di Jakarta Timur tertinggi terjadi pada kategori peralatan ibadah kemudian kategori jilbab dan pakaian muslim pria, penjualan rata-rata harian di Jakarta Selatan tertinggi terjadi pada kategori peralatan ibadah kemudian kategori jilbab dan pakaian muslim pria, penjualan rata-rata harian di Jakarta Barat tertinggi terjadi pada kategori peralatan ibadah kemudian atasan wanita dan pakaian muslim pria. 


\section{c. Analisis Unit Terjual Tiap Sub Kategori}

Analisis penjualan produk fashion muslim menurut kategori dan subkategori pada masing-masing kota di DKI Jakarta dilakukan dengan menggunakan radar chart. Gambar 10 menunjukkan radar chart penjualan produk fashion muslim menurut kategorinya.

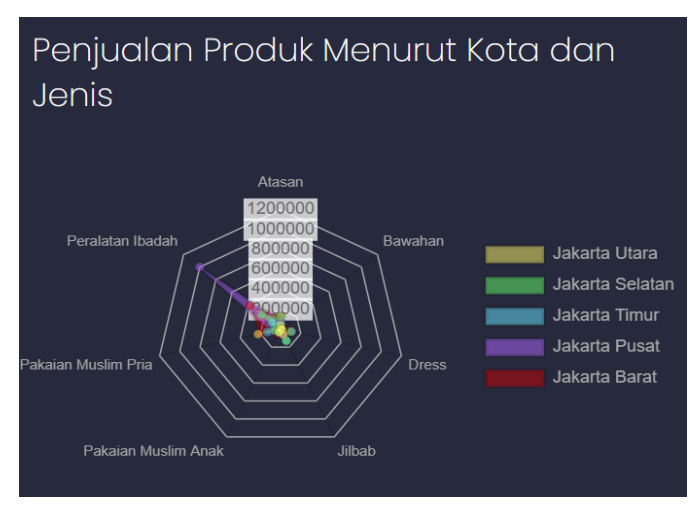

Gambar 13. Radar Chart Penjualan Produk Fashion Muslim Menurut Kategorinya

Berdasarkan gambar tersebut, dapat terlihat bahwa penjualan produk fashion muslim terbanyak terjadi pada kategori peralatan ibadah di Jakarta Pusat, kemudian dilanjutkan peralatan ibadah di Jakarta Barat.

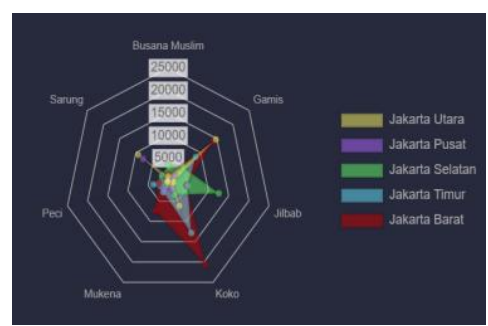

a. Penjualan Pakaian Muslim Anak

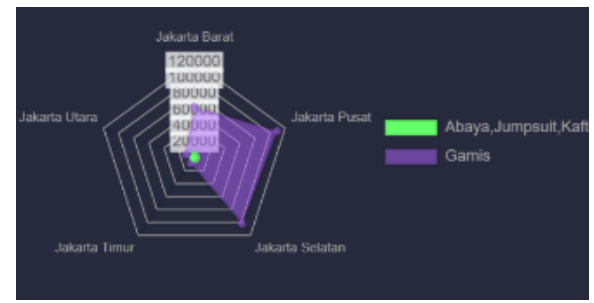

d. Penjualan Dress Muslim Wanita

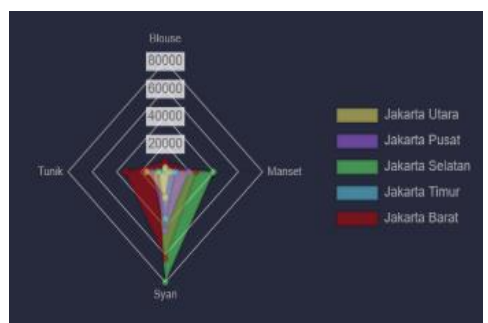

b. Penjualan Atasan Muslim Wanita

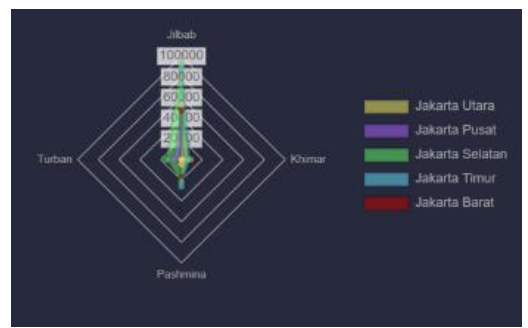

e. Penjualan Jilbab

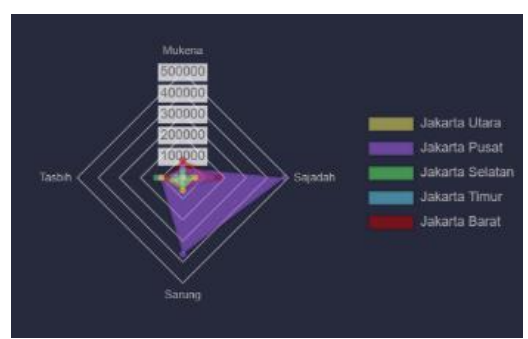

g. Penjualan Peralatan Ibadah

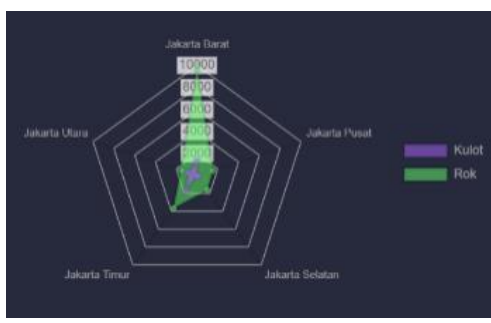

c. Penjualan Bawahan Muslim Wanita

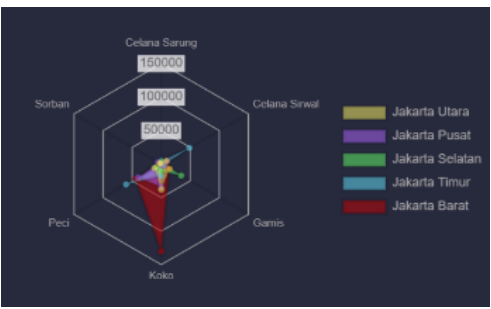

f. Penjualan Pakaian Muslim Pria

Gambar 14. Radar Chart Penjualan Produk Fashion Muslim Menurut Sub Kategorinya di DKI Jakarta

Gambar 14 menunjukkan radar chart penjualan produk fashion muslim di DKI Jakarta menurut kota dan sub kategorinya. Berdasarkan gambar tersebut, dapat terlihat bahwa penjualan pakaian muslim anak tertinggi terjadi pada sub kategori baju koko di Jakarta Barat, penjualan atasan muslim wanita tertinggi terjadi pada sub kategori baju syari di Jakarta Selatan, penjualan bawahan muslim wanita tertinggi terjadi pada sub kategori rok di Jakarta Barat, penjualan dress muslim wanita tertinggi terjadi pada subkategori gamis di Jakarta Pusat dan Selatan, penjualan jilbab tertinggi terjadi pada sub kategori jilbab koko di Jakarta Selatan, penjualan pakaian muslim pria tertinggi terjadi pada sub kategori baju koko di Jakarta Barat, penjualan peralatan ibadah tertinggi terjadi pada sub kategori sajadah dan sarung di Jakarta Pusat. 


\section{Pengujian Dashboard}

Untuk melihat kelayakan dashboard yang telah dibangun. Dilakukan pengujian dashboard dengan hasil yang ditunjukkan pada Gambar 15.

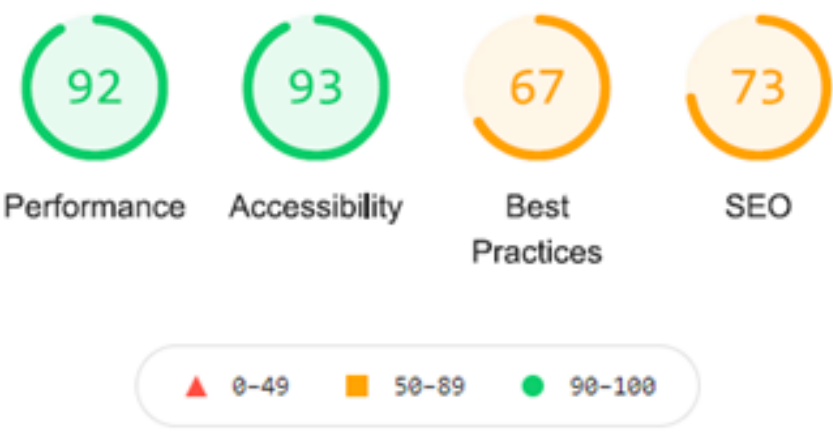

Gambar 15. Hasil Pengujian Dashboard

Dari hasil pengujian menggunakan Lighthouse, dashboard penjualan pakaian muslim selama ramadhan memiliki nilai kinerja sebesar 92 dari 100. Untuk aksesibilitas dashboard ini memiliki nilai 93, untuk best practices memiliki nilai 67, dan untuk SEO memiliki nilai 73 dari 100. Menurut kriteria dari lighthouse nilai hasil pengujian kurang dari 50 memiliki kriteria buruk, 50 hingga 89 memiliki kriteria cukup, dan di atas 90 memiliki kriteria baik. Sehingga dapat disimpulkan untuk kategori best practices dan SEO memiliki kriteria cukup dan untuk kategori kinerja dan aksesibilitas memiliki kriteria baik.

\section{KESIMPULAN}

Dari penelitian ini, information dashboard visualisasi data penjualan produk fashion muslim melalui Tokopedia di DKI Jakarta pada Bulan Ramadhan telah berhasil dibangun dengan performa yang baik. Visualisasi pada dashboard tersebut disajikan menggunakan line chart, pie chart, bar chart, radar chart, dan choropleth map. Hasil analisis deskriptif pada setiap visualisasi yang disajikan menunjukkan bahwa secara umum, penjualan produk fashion muslim cenderung tinggi di awal dan di pertengahan bulan Ramadhan. Wilayah DKI Jakarta dengan kontribusi penjualan produk fashion muslim terbanyak adalah Jakarta Pusat, sedangkan wilayah dengan omset penjualan produk fashion muslim tertinggi adalah Jakarta Barat. Diharapkan, information dashboard yang dibangun ini dapat memberikan informasi kepada pemerintah daerah dan masyarakat umum sebagai pelaku usaha mengenai potensi e-commerce khususnya produk fashion muslim di daerahnya sehingga dapat mendukung kebijakan strategi pemulihan ekonomi nasional (PEN).

\section{DAFTAR PUSTAKA}

A.Yani, D. D., Pratiwi, H. S., \& Muhardi, H. (2019). Implementasi Web Scraping untuk Pengambilan Data pada Situs Marketplace. Jurnal Sistem Dan Teknologi Informasi (JUSTIN), 7(4), 257. https://doi.org/10.26418/justin.v7i4.30930/.

Ariyanti, A., 2021. https://analisis.kontan.co.id/news/memaknai-kontraksi-ekonomi-indonesia. Diakses pada 12 Juni 2021

Badan Pusat Statistik Jakarta Pusat. (2010). Statistik E-Commerce 2010. Jakarta Pusat : Badan Pusat Statistik

Bertuah, E., Wicaksono, S.M., 2021. Perbandingan Perilaku Belanja Online Melalui Shopee Dan Tokopedia Di Masa Pandemi Covid-19

Dinisari, M.C. (2020). https://ekonomi.bisnis.com/read/20200417/12/1228750/e-commerce-dorongperekonomian-indonesia-selama-pandemi-covid-19-. Diakses 18 Juni 2021

Febriantoro, W. (2018). Kajian dan strategi pendukung perkembangan e-commerce bagi UMKM di Indonesia. Manajerial: Jurnal Manajemen dan Sistem Informasi, 17(2), pp.184-207.

Google Developers. (2020). Lighthouse. https://developers.google.com/web/tools/lighthouse/. Diakses: 4 September 2021.

Junaedi, H., Budianto, H., Maryati, I., \& Melani, Y. (2011). Data transformation pada data mining. Prosiding Konferensi Nasional Inovasi dalam Desain dan Teknologi-IDeaTech, 93-99.

Lee, C. (2018). Belajar Visualisasi Data dengan Grafis dan Infografis Step-by-Step. Elex Media Komputindo. 
Mardiah, A. (2019). Analisis perilaku konsumtif masyarakat muslim menjelang Idul Fitri di Kota Pekanbaru. Jurnal Al-Iqtishad, 13(2), pp.93-103

Mazza, Riccardo. (2008). Introduction to Information Visualization. Lugano: Springer DOI: 10.1007/978-1-84800219-7.J. Clerk Maxwell, A Treatise on Electricity and Magnetism, 3rd ed., vol. 2. Oxford: Clarendon, 1892, pp.68-73.

Moore, J. (2017). Data visualization in support of executive decision making. Interdisciplinary Journal of Information, Knowledge, and Management, 12, 125-138.

Nainggolan, E.U.P. (2020). https://www.djkn.kemenkeu.go.id/artikel/baca/13287/Strategi-Kebijakan-PemulihanEkonomi-Nasional.html. Diakes pada 1 Juni 2021

Namitha, K., Narayanan, A., \& Geetha, M. (2021). Interactive visualization-based surveillance video synopsis. Applied Intelligence, 1-22.

Pakpahan, A.K. (2020). Covid-19 Dan Implikasi Bagi Usaha Mikro, Kecil, Dan Menengah. Jurnal Ilmiah Hubungan Internasional, pp.59-64.

Summers, S. H. (2017). Preattentive Attributes in Visualization Design: Enhancing Combat Identification. In Human Factors Issues in Combat Identification (pp. 129-144). CRC Press.

Tokopedia (2021, 20 Mei). Tokopedia Ungkap Transaksi Selama Ramadan. Kontan Pressrelease. https://pressrelease.kontan.co.id/release/tokopedia-ungkap-transaksi-selama-ramadan

Vincentdo, V., Pratama, A. R., Girsang, A. S., Suwandi, R., \& Andrean, Y. P. (2019, November). Reporting and Decision Support Using Data Warehouse for E-Commerce top-up Cell-phone Credit Transaction. In 2019 tth International Conference on Cyber and IT Service Management (CITSM) (Vol. 7, pp. 1-4). IEEE.

Wahid, A. A. (2020). Analisis Metode Waterfall Untuk Pengembangan Sistem Informasi. Jurnal Ilmu-Ilmu Informatika Dan Manajemen STMIK, October, 1-5. 